\title{
Diariusze oblężenia Jasnej Góry w roku 1771
}

Jacek Wójcicki. 
nAPIS Seria VI 2000

\title{
Diariusze oblężenia Jasnej Góry w roku 1771
}

\author{
Opracował Jacek Wójcicki
}

$\mathrm{F}$ ortecę częstochowską, zajętą od września 1770 roku przez załogę konfederacką pod komendą Kazimierza Pulaskiego, oblegały na początku stycznia 1771 wojska rosyjskie, dowodzone przez osławionego Iwana Drewitza. Jej dwutygodniowa obrona należy do tych przełomowych wydarzeń konfederacji barskiej, które zostały najlepiej udokumentowane w obiegowej literaturze okolicznościowej. Wiadomości o bohaterskiej postawie barskich żołnierzy i mało skutecznych usiłowaniach Rosjan docierały do ogółu zwykłą drogą półprywatnych listów ${ }^{1}$, gazetek pisanych ${ }^{2}$, a za granicę - doniesień dziennikarskich. Nie brakowało też poezji ulotnej, jak Larum $w$ czasie przypuszczonego przez Drewitza... do fortecy częstochowskiej szturmu... ${ }^{3}$ Po kraju kursowały również szczególowe diariusze oblężenia, spisywane przez obrońców bądź na bieżąco, bądź opracowywane szerzej z notatek potocznych już po odstąpieniu Drewitza, zarówno zrezygnowanego bezowocnością starań oblężniczych, jak i zmuszonego do wycofania się w stronę atakowanego właśnie przez konfederację Krakowa.

Obrona Częstochowy przynosiła zaszczyt załodze i osobiście talentom młodego dowódcy, prowadzącego $z$ warowni śmiale wypady na pozycje wroga ${ }^{4}$. Co ważniejsze jednak, stanowiła zarazem - ze względu na wyjątkowe znaczenie jasnogórskiego sanktuarium oraz podkreślane analogie $z$ wcześniejszym o ponad sto lat najazdem szwedzkim i czynami przeora

\footnotetext{
' Zob. np. rpsy Biblioteki Czartoryskich w Krakowie (dalej: B Czart), sygn. 836, s. 721 (list marszałka Stanisława Lubomirskiego); 842, s. 411-415 (pismo z 23 VI 1771).

${ }^{2}$ Zob. np. wieści z Warszawy dn. 30 I 1771 z teki odpisów Szczęsnego Morawskiego - rps Biblioteki PAN w Krakowie (dalej: PAN Kr) sygn. 1147, k. 254-254 v.

${ }^{3}$ Z rękopisu B Czart 865, s. 419-420, ogłoszony w: Poezja barska, opr. K. Kolbuszewski, Kraków 1928 (BN I 108), s. 62-64; Literatura barska (Antologia), opr. J. Maciejewski, Wroclaw 1976 (BN I 108), s. 333-335.

${ }^{4}$ „Był jedynym wodzem konfederackim, którego talent fortyfikacyjny w pełni doceniają i chwalą historycy rosyjscy" - pisze o Pułaskim autor najnowszej monografii Jasnej Góry z punktu widzenia znawcy sztuki oblężniczej, Ryszard Henryk Bochenek (Twierdza Jasna Góra, Warszawa 1997, s. 168). Obronie barzan przed Rosjanami poświęcony został tu rozdział 7 (s. 165-185, w tym na s. 177-185 - wzorem dawnych epok opis działań wojennych w formie syntetycznego diariusza).
} 
Kordeckiego - ważny element propagandy patriotycznej o charakterze religijnym. Jasna Góra znów stawała się znakiem przetrwania przy nadzwyczajnej opiece Bogarodzicy — co tuż po oblężeniu utrwalono symbolicznie w odznaczeniu, którego jedyny egzemplarz zachował się w zbiorach klasztoru ${ }^{5}$. Konfederaci opuścili fortecę dopiero w dniu ostatecznej kapitulacji 18 VIII 1772, po następnych, już bardziej bezwzględnych i skutecznych oblężeniach.

Niestety, fama była bodaj największą korzyścią z akcji militarnej ze stycznia 1771 roku, która pozostała zaledwie epizodem działań zbrojnych schyłku konfederacji. Konflikty wśród starszyzny prowadzity do podsycanej przez Generalność rywalizacji między Pułaskim a regimentarzem wielkopolskim Józefem Zarembą. Chociaż ten, jak wynikało z krążących nowin, przyczynił się do kapitulacji Moskali ${ }^{6}$, nie poparł jednak oblężonych stanowczym, prędkim uderzeniem (podobnie jak dowódcy innych, mniejszych oddziałów walczących wówczas w okolicach Częstochowy). Nie dozwoliło to wykorzystać w pełni strategicznej wartości obronienia fortecy przed znacznie przeważającymi, ale srodze pod murami warowni wykrwawionymi siłami Drewitza.

\section{Przegląd odpisów}

O masowym rozpowszechnieniu diariuszy świadczy duża ich liczba w obecnych zbiorach rękopiśmiennych, grupujących przecież tylko część będących w rzeczywistym obiegu pism. W związku z tym obecna edycja, mimo dążenia do w miarę pełnego zilustrowania zmian, jakim domniemane pierwowzory ulegały w kolejnych odpisach, opiera się tylko na ich reprezentatywnej grupie, z pewnością nie wyczerpujących wszystkich możliwych odmian tekstu. Zmianom i zniekształceniom ulegały przede wszystkim nazwy miejscowości i nazwiska wojskowych, trudne nieraz do jednoznacznego zrekonstruowania. Zmieniały się również - ale bardziej z przyczyny świadomej propagandy niż tylko z powodu skażeń kolejnych

\footnotetext{
${ }^{5}$ Odznaczenie, w formie brązowego krzyża kawalerskiego z biało-czerwonymi emaliowanymi płomieniami spomiędzy ramion oraz z wizerunkami Matki Boskiej z Dzieciątkiem na awersie i białym orłem na rewersie emaliowanej tarczy centralnej, ustanowiono i zapewne wręczono przy święcie Matki Boskiej Gromnicznej 2 lutego 1771 z rozkazu Pulaskiego jako komendanta obrońcom twierdzy. Na awersie wyryto w miedzianej blasze napisy: PRO FIDE/ET MARIA/PRO LEGE/ET PATRIA; w otoku: MARIA VICTRIX HOSTIUM. W otoku orla na rewersie hasło: IN HOC SIGNO VINCES. Skrótowe (i dodajmy, że dosyć topornie wykonane) napisy na odwrocie ramion krzyża: CAS[IMIR] PUŁA[SKI] / MAR[ESCHALLUS] LOMZ[ENSIS] / TRIB[UIT] PRAEMIU[M] / BENE MER[ENTI] IN CL[ARO] MONTE D[IE] 2 FE[BRUARII] 1771 oraz jego unikatowy charakter każą niektórym przypuszczać, że dysponentem krzyża był konwent pauliński, a jedynym odznaczonym - sam Pułaski (zob. C. Brodzicki, Kazimierz Pulaski marszalek tomżyński, Łomża 1988, s. 68-69 - tu również ilustracja i przekład dwu możliwych rozwiązań inskrypcji). Wówczas napis należaloby czytać: BENE MER[ENTI] (...)/CAS[IMIRO] PUŁA[SKI]/MAR[ESCHALLO] LOMZ[ENSI] / TRIB[UITUR] PRAEMIU[M]. Bochenek (op. cit., s. 184) sądzi, że bylo to jednak odznaczenie dla wyróżniających się obrońców i w tym duchu rozwiązuje skróty („bene merentibus”), lecz napisy na krzyżu cytuje niedokładnie.

${ }^{6}$ „Gdy zaś Moskwie zaczęło prochu brakować, wysłała po niego na Śląsk, któren prowadząc JP Zaremba odbil, o czym dowiedziawszy się i o sukcesie konfederackim usłyszawszy, die 16 od fortecy odstapiła (...)" (rps PAN Kr 1147, k. 254 v. - zob. przypis 2).
} 
odpisów — dane ilościowe. $Z$ reguły zawyżano liczbę wojsk nieprzyjaciela oraz siłę poszczególnych ataków i bombardowań, za to wymiary strat własnych pomniejszano odwrotnie proporcjonalnie do ubytków w szeregach przeciwnika ${ }^{7}$.

Prócz przekazów rękopiśmiennych, zawartych bądź w sylwach szlacheckich, bądź przepisywanych oddzielnie, nieraz w kształcie swego rodzaju modlitewników, materiału porównawczego dostarczyły również czasopisma i inne publikacje dziewiętnastowieczne. Można jednak potraktować je jako wierne kopie manuskryptów, za czym przemawiaja... błędy i nonsensy tekstu, pozostawione in crudo bez ingerencji redaktorów.

Już pierwsze porównania relacji o obronie Jasnej Góry pozwoliły wyodrębnić, obok jednostkowych doniesień (jak wspomniane wyżej listy i gazetki, czy też bardzo ciekawy, niestety mocno zdefektowany odpis, ukazujący kulisy nieudanej rosyjskiej dywersji wśród obrońców $\left.{ }^{8}\right)$, dwa podstawowe warianty diariusza. Kryterium podziału nie stanowi przy tym kilka odmian tytułu: Dyjaryjusz od podstapienia wojska moskiewskiego pod Jasną Górę Częstochowska... a az do cofnienia onegoż...; Dyjaryjusz ataku fortecy częstochowskiej wojskiem konfederackim osadzonej przez wojsko moskiewskie uczynionego; (Rzetelna) Informacyja o oblężeniu i ataku fortecy częstochowskiej... - ponieważ pod podobnym nagłówkiem kursować mogły obie wersje. Czasami też kopiści uzupełniali relację informacjami z obu wersji jednocześnie.

\section{Wersja „A”}

Wersję A stanowi tekst krótszy, spisywany, jak się wydaje, z dnia na dzień przez kronikarza konfederacji. Nie był to raczej zakonnik, choć tak sugerują tytuły niektórych odpisów. Pamiętać bowiem należy o obojętnej lub wręcz wrogiej wobec konfederacji postawie paulinów częstochowskich, którzy musieli pogodzić się z naruszeniem pożądanej neutralności klasztoru po wtargnięciu Pułaskiego ze swymi ludźmi gwałtem i nie bez krwawej utarczki.

Podstawą edycji tej wersji jest rękopis Biblioteki Jagiellońskiej w Krakowie (dalej: BJ) sygn. 3049, jeden z tomów Ciekawości czasów barskich zebranych przez Tadeusza Lipskiego 9 Zamieszczony w zbiorze wydarzeń roku 1771 odpis jest najkompletniejszy i dobrze czytelny, niemniej należy zaznaczyć, że spisujący poczynił kilka poprawek stylistycznych, czym różni się nieznacznie od reszty kopii, przepisywanych bardziej mechanicznie ${ }^{10}$.

Dwa egzemplarze wersji A znajdują się również w Bibliotece Kórnickiej (dalej: BK), sygn. 2110 bl. 5 oraz BK 13304. Pierwszy z nich pochodzi z archiwum Józefa Zaremby,

\footnotetext{
7 Siłę atakujących w grudniu 1770 roku historyk wojskowości ustala obecnie na ok. 4 tysiące żołnierzy i 24 działa, zaś garnizon twierdzy ocenia na 1450 żołnierzy i 40 armat (R. H. Bochenek, op. cit., s. 180).

${ }^{8}$ Zob. rękopis Biblioteki Zakładu Narodowego im. Ossolińskich we Wrocławiu (dalej: Ossol.) sygn. 1835, k. 59-62 v.

9 Zob. W. Konopczyński, Konfederacja Barska. Przegląd źródel, „Kwartalnik Historyczny” LXVIII 1934 z. 3, s. 545-546, poz. 14.

${ }^{10}$ Kopista zastąpił np. używane w pozostałych odpisach określenia „plejzer”, „plejzerowany” (z franc. blessure) synonimami „rana”, „ranny”.
} 
dobrze poinformowanego o działaniach ambitnego konkurenta, Pułaskiego, i o zdarzeniach pod Jasną Górą - w tej samej tece jest i druga wersja diariusza, o czym niżej.

Poza wymienionymi trzema odpisami porównano jeszcze:

4. Rps PAN Kr 670, k. 126-128 (Informacyja o oblężeniu i ataku... przez jednego konfederata skonotowana);

5. Druk w „Pamiętniku Sandomierskim” (dalej: Pam. Sand.) 1830 t. 7, s. 385-398 (Rzetelna informacyja... przez zakonnika ${ }^{11}$;

6. Diariusz opublikowany przez Leonarda Chodźkę, Żywot Kazimierza na Pulaziu Pulaskiego..., Lwów 1869, s. 72-79 (dalej: Chodźko) - zwięzły, „przez jednego zakonnika skreślony".

Tekst wersji A stal się podstawą dla wariantu jeszcze bardziej skróconego i zbierającego nieraz wydarzenia kilku dni w jednej wzmiance, który mimo różnic stylistycznych wobec wariantu obszerniejszego mógł posłużyć jako materiał porównawczy. Reprezentuja go:

7. Rps Ossol. 568, s. 249-253 (Dyjaryjusz od podstapienia wojska moskiewskiego ... aż do cofnienia onego $\dot{z} . ..)^{12}$

8. Rps Ossol. 3465 (Dyjaryjusz ataku fortecy Jasnej Góry Częstochowskiej... któren po cofnięciu się nieprzyjacielskich od oblężeńców wydany) - $\mathrm{w}$ formie osobnej książeczki, uzupełnionej na końcu modlitwą do Matki Boskiej Częstochowskiej;

9. Rps B Czart 842, s. 357-358;

10. Rps BJ 5501, k. 146-147 v. (Dyjaryjusz od podstapienia wojska moskiewskiego...);

11. Rps BJ Przyb. 171/51 „B”, k. 137-139 v. (Dyjaryjusz od podstapienia ...);

12. Rps PAN Kr 1152 (Dzieje polskie czyli przypadki znaczniejsze za panowania... Stanistawa Augusta... zdarzone, t. 3) — relacja o oblężeniu Częstochowy (Opisanie ataku... przez dwa tygodnie trwającego) zajmuje s. 1-9; datowanie wydarzeń przesunięte jest o jeden dzień naprzód.

Prócz tego wersję A wykorzystują rękopisy Ossol. 573, s. 51-54, oraz BJ Przyb. 171/51 „A”, k. 133-135 v. (Dyjaryjusz w krótkości z wielkiego dyjaryjuszu uyciagniony), inne od poprzednich. Wersję A (z racji znacznych ubytków tekstu nie wiadomo, który to wariant) znajdujemy również w silnie zdefektowanym rękopisie Biblioteki Uniwersyteckiej w Warszawie (dalej: BUW) sygn. 274 t. 4, s. 1429-1435.

W wersji A opis wydarzeń 7 stycznia rozpoczyna się charakterystycznym zwrotem, iz dzień ów „fatalny był szpiegowi dziewce”, na końcu zaś znajduje się Dyspozycyja (Rozporzqdzenie) oficyjerów. Znajdujemy tu zazwyczaj również wstęp o komecie z 5 (lub 6) grudnia 1768 roku, który naśladuje - zapewne całkiem świadomie — początek Nowej Gigantomachii

\footnotetext{
"Wspomniał o tej wersji pierwszy monografista Baru, Stanisław Kaczkowski, w swoich Wiadomościach o Konfederacji Barskiej, Poznań 1843, s. 195; wykorzystał ją również Stanisław Kwasieborski w obszernej rozprawie Częstochowa za Konfederacji Barskiej, Warszawa 1917, dokonując analizy porównawczej kilku wersji diariusza $\mathrm{w}$ dążeniu do odtworzenia rzeczywistego przebiegu wydarzeń.

12 Wykorzystany przez Kwasieborskiego (zob. przypis poprzedni).
} 
przeora Kordeckiego. Autor diariusza potraktował kometę w ten sam sposób, w jaki jego wielki poprzednik pożar klasztoru, spowodowany uderzeniem pioruna 10 lutego 1654 roku, a następnie przerażający „znak na niebie, który się zdarzył tegoż samego roku 9 czerwca na twarzy zachodzącego słońca"13 — jako omen, które Bóg „zesłał pierw ku upamiętaniu”, kiedy to

Nim miecza dobył, nim ci dał stych jaki,

Że cię miał skarać, dawał znać przez znaki.

Na wielu miejscach stawiał przed wzrok człeczy

Z ziemie i z morza dziwne barzo rzeczy ${ }^{15}$.

Być może osiemnastowieczny diariusz oblężenia już od początku jawił się w zamiarach autora jako materiał do przyszłej „epopei moralnej” (w czym Mickiewicz upatrywał najwyższy walor Nowej Gigantomachii Kordeckiego ${ }^{16}$ ). Nie sposób odgadnąć, czy autor zapisków od razu przewidywał bezskuteczność ataków przeciwnika - raczej poetyka takiego diariusza zakładała a priori w każdym wypadku moralne zwycięstwo oblężonych, bo nawet przegrana konfederatów mogła być w przyszłości zinterpretowana jako słuszna kara Boska i jeszcze wyraźniejszy znak z niebios. Warto zresztą zauważyć, że w świetle obu wersji diariusza konfederaci barscy odnieśli sukces tylko w części — prawda, że ogromnej — dzięki własnym staraniom. Kapitulację przyspieszył bowiem, według opisów pod datą 14 stycznia, nagły zgon kilku oficerów moskiewskich i zranienie brata dowódcy, srodze zatrwożonego tymi znakami. Niewykluczone, że ten powtarzany z ust do ust powód odstąpienia Drewitza więcej wspólnego niż z rzeczywistością ma z legendarnym przetworzeniem epizodu oblężenia szwedzkiego z 12 grudnia 1655 roku, kiedy to podczas polskiego ostrzału kwatery generała Müllera zginął - jak powiadano - jego siostrzeniec ${ }^{17}$.

\section{Wersja „B”}

Wersja B jest obszerniejsza, pisana, jak sądzi Kwasieborski, „niezawodnie przez wojskowego i uczestnika walk, który patrzył na wszystko z bliska” ${ }^{\prime 18}$.

\footnotetext{
$13{ }_{n}$ Nad nosem słońca widziano krzyż, przemieniający się w serce, które mieczem przeszyte chyląc się na stronę lewą stanęło pod okiem. Pod drugim zaś okiem twarzy słonecznej widziano rękę, jabłko trzymająca jabłko to wznosiło się po oku ku czołowi rozdzieliwszy się na cztery części, a gdy wypłynęło ponad tarczę słońca, przedstawiło rózgę" - A. Kordecki, Pamiętnik oblężenia Czestochowy 1655 r., tł. J. Łebkowski, Częstochowa 1991, s. 17 (przekład z r. 1858).

${ }^{14}$ Ibid.

${ }^{15}$ W. Odymalski, Obleżenia Jasnej Góry Cz̨̧stochowskiej pieśni dwanaście, wyd. J. Czubek, Kraków 1930 (BPP 83), s. 12 (koniec strofy 19. i początek 20.); w najnowszych badaniach autorstwo tego poematu, genetycznie zależnego od dzieła Kordeckiego, przysądza się redaktorowi lacińskiego tekstu Nowej Gigantomachii (wydanej $z$ datą 1655, lecz w istocie najwcześniej na jesieni 1657 roku), Stefanowi Damalewiczowi - zob. R. Ocieczek, „Obleżenie Jasnej Góry Częstochowskiej”. Dzielo i autor, Kraków 1993.

${ }^{16}$ Zob. A. Mickiewicz, Literatura stowiańska. Kurs drugi, Warszawa 1952 (Wydanie Narodowe t. X), s. 53 (wykład IV z 4 I 1842) i 57 (wykład V z 7 I 1842).

17 Zob. R. H. Bochenek, op. cit., s. 86.

${ }^{18}$ S. Kwasieborski, op. cit., s. 159 (zarazem wersję diariusza z „Pamiętnika Sandomierskiego” historyk uznaje
} 
Wykorzystano następujące kopie rękopiśmienne i przekazy drukowane:

1. Rps B Czart 865, s. 345-358 (tekst podstawowy);

2. Rps B Czart 830, s. 135-147 (Dyjaryjusz od podstapienia...) ${ }^{19}$;

3. Rps Ossol. 6152, s. 31-37 (Dyjaryjusz od podstapienia...);

4. Rps Pawl. 94 (Zbiory Pawlikowskich — obecnie w Ossolineum we Wroclawiu). Tekst ciekawy, mimo wielu błędów, zarówno ze względu na dążenie do syntezy obu wersji (wstęp o komecie według wersji A, uzupełnienia w tekście), jak i formę osobnej książeczki, naśladującej druk;

5. Rps BK 2110 bl. 5 - z archiwum Józefa Zaremby;

6. Druk „Z rękopismów pana N. Rasińskiego” w „Przyjacielu Ludu” (Leszno) 1841, nry 37-39, s. 291-295, 297-299, 307-308 (dalej: Prz. Ludu) ${ }^{20}$;

7. Druk w monografii genealogiczno-historycznej rodu Pułaskich pióra Kazimierza Pułaskiego (dalej: Puł.) ${ }^{21}$. Lukę w tekście wydawca uzupełnia fragmentami diariusza z pracy Chodźki ${ }^{22}$.

Wersja B pomija między innymi wstęp o nadzwyczajnych zjawiskach niebieskich oraz dyspozycję oficerów.

\section{Wersja ,jasnogórska”}

Oprócz wersji A (w wariancie dłuższym i krótszym) oraz B istnieje również tekst odmienny od wymienionych, zatytułowany Dyjaryjusz od podstapienia nieprzyjaciela pod fortece Jasnej Góry die 31 grudnia 1770 roku, w jednym zaledwie egzemplarzu. Jest to wszakże dokument niezwykle istotny, znajduje się bowiem w Archiwum Jasnogórskim OO. Paulinów (dalej: AJP), gdzie wpisano go do kroniki prowincjalnej okresu od 13 X 1759 do 17 IX $1780^{23}$. Znamy więc i spojrzenie $z$ wewnątrz oblężonej twierdzy, do tego $z$ punktu widzenia przymusowych, znękanych i niekoniecznie przychylnych obserwatorów. Kronikarz zakonny w łacińskiej notatce na s. 427 informuje skrótowo o rozpoczęciu, a niebawem i o zakończeniu oblężenia i uprowadzeniu zakonników (wymienia nazwiska: mistrza nowicjatu Bonawentury Maresza, Kazimierza Zaręby, Alfonsa Mirskiego i Dionizego Pietrzykowskiego). Usprawiedliwia się, że nie dysponując w danej chwili dokładnym diariuszem, pozostawia wolne dwie strony do późniejszego uzupełnienia za pomocą źródeł klasztornych lub jakich-

za dzieło zakonnika - zob. ibid., przypis na s. 151).

19 Wykorzystany przez Kwasieborskiego (zob. przypis 8).

${ }^{20}$ Wykorzystany przez Kwasieborskiego (zob. wyżej).

${ }^{21}$ Wydana anonimowo w: T. Żychliński, Ztota ksiega szlachty polskiej, t. 8, Poznań 1886, s. 338-346.

${ }^{22} \mathrm{~W}$ skróceniu przedrukowany w: W. Konopczyński, Konfederacja barska. Wybór tekstów, Kraków 1928 (BN I 102), s. 120-127; fragment odpisu B Czart 865, uzupełniający lukę w relacji opublikowanej przez K. Pułaskiego, przedrukował Konopczyński w Materialach do dziejów wojny konfederackiej 1768-1774 r., Kraków 1931, s. 102-104.

${ }^{23}$ Zob. AJP sygn. 540, Actorum provinciae Polonae tomus XI..., s. 427-429 oraz 830-833 (dawniej 1124-1127). 
kolwiek innych, o ile tylko ukażą prawdę o zdarzeniach („dummodo ipse nucleus veritatis exprimi possit"). Dopisany później diariusz w języku polskim (miejscami suchy, miejscami bardzo dynamiczny, zwłaszcza w opisie szturmu z 9 stycznia), chociaż zwięzły, nie zmieścił się na przewidzianym miejscu, stąd wykorzystano również sam koniec kodeksu. Kiedy dokonano wpisu — dokładnie nie wiadomo. Prawdziwość dokumentu („de originalibus copiis exaratum”) poświadcza znacznie późniejsza, zamieszczona pod tekstem łacińska notatka sekretarza prowincji polskiej paulinów ${ }^{24}$.

Rzekoma inspiracja króla Stanisława Augusta, jakoby zachęcającego Rosjan do atakowania Częstochowy, stała się motywem publicystycznego Listu konfederata do Jego Królewskiej Mości względem odstapienia imprezy' ataku Częstochowy, rozpowszechnionego w licznych odpisach ${ }^{25}$. Datowana na 1 listopada 1770 roku epistoła pomstuje na niezliczone "gwałty” i „tyraństwa” pod rządami króla, a w szczególności na poniżenie wiary katolickiej. „Sprzysiężony konfederat" wierzy, że monarcha pragnie dotrzymać przysięgi koronacyjnej, lecz tylko omamili go dworzanie i urzędnicy, „wyrodki ojczyzny” („śmierć, zguba, tyranija nad bracią i współobywatelami dokonane - to dla nich radość, to jedyna serca ich pociecha”) ${ }^{26}$. Traci jednak cierpliwość, oto bowiem

Dochodzą nas wiadomości, iż na wojennej rosyjskiej radzie atak Jasnej Góry jest decydowany. Mamy w Bogu nadzieję i obronie Nieba Królowej, iż od tej fortecy, przykładem niegdyś bezbożnych Szwedów, dziś także zuchwały nieprzyjaciel odejdzie z hańbą i ze wstydem. A jeżeli się inaczej Bogu podoba, to przynajmniej nie inaczej tam trafi, tylko po naszych karkach i mogiłach.

Ale żeby ten atak miał nastąpić od wojska auksylijarnego Waszej Królewskiej Mości, natenczas sama chyba Wszechmocność zemstę, niechęć, nienawiść do rządów i panowania Waszej Królewskiej Mości w nas i potomkach naszych ukoić i wykorzenić potrafi ${ }^{27}$.

\footnotetext{
${ }^{24}$ Byl nim Urban Pawel Porubski OSPE (1784-1830); z całą pewnością, wbrew twierdzeniu biogramu pióra ks. Janusza Zbudniewka w Stowniku polskich teologów katolickich (t. 3, Warszawa 1982, s. 423), nie jest on autorem tego diariusza, nazwanego zresztą mylnie „najstarszym zapisem” wydarzeń oblężenia przez Bochenka (zob. Twierdza Jasıa Góra, s. 177).

${ }^{25}$ Odpisy kursowały pod tytułem w dwóch wariantach:

List (List konfederata) do JKMci... zob. rpsy B Czart 865, s. 385-388; BJ 6673 II, s. 746-753; Ossol. 194, k. 94 v.-96; Ossol. 330, k. 30-31 v.; Ossol. 332, k. 49-50; Ossol. 1077, k. 69-70; Ossol. 1409, s. 407-415; PAN Kr 670, k. 123-124; Kopia listu do JKMci... zob. rpsy B Czart 842, s. 159-161; B Czart 1170, s. 543-546; BN Akc. 1983, k. 148-149 v.; PAN Kr 1681, s. 20-23; BUW 137, k. 15; BUW 274 t. IV, s. 1426-1429; Pawl. 238, s. 435-439.

${ }^{26}$ Cyt. za rpsem Pawl. 238, s. 438.

${ }^{27}$ Pawl. 238, s. 438-439.
} 
W istocie List konfederata powstał w marcu 1771 roku, czyli wówczas, gdy przywoływany na opamiętanie Stanisława Augusta straszak bezkrólewia był już faktem. Dowodzi tego polemiczne Przettumaczenie listu znajdującego się $w$ drugim tomie książki francuskiej pod tytutem „Dyjaryjusz historyczny”..., powstałe $z$ inspiracji królewskiej, a znane z licznych druków i kopii rękopiśmiennych:

Nie masz nikogo w Warszawie, który by nie wiedział starania królewskiego o oddalenie ułożonego Częstochowy oblężenia. Za jego rozkazem podało ministeryjum posłowi rosyjskiemu reprezentacyją i żądanie, ażeby to miejsce, powszechnym nabożeństwem wsławione, ochronione było. Świadkami tego są rezydujący w Warszawie ministrowie cudzoziemscy. Autor pisma sam dobrze wiedział o tym, pismo zaś jego rozrzucone we dwa miesiące po oddaniu zwyż wzmiankowanej ministeryjalnej rekwizycyi, a w sześć niedziel po wykonanym bezskutecznie ataku, zdaje się dopiero żądać jego odwrócenia; dlatego kładzie antydatę swojego listu, i uchwyciwszy się późno zmyślonego Częstochowy ratunku, rozwija pod tym pretekstem uknowaną dawniej samej złości osnowę $e^{28}$.

Mniemane „tłumaczenie” wywołało kolejne kontry i repliki, była to jednak akcja publicystyczna daleka już od militarnego punktu wyjścia - oblężenia Jasnej Góry, służącego w tej wymianie poglądów ogólnych na politykę króla jedynie jako pars pro toto ${ }^{29}$.

W obecnej edycji diariuszy nie ujednolicono pisowni nazwiska Drewitz (Drewlicz, Derewicz), sprowadzając jednak częstą oboczność pisowni Pułaski/Puławski do formy właściwej. Pozostawiono również bez zmian niekonsekwentny zapis liczebników (słownie bądź cyframi). Rozwiązano bez oznaczenia skróty tytułów: JMP (imć pan), JO (jaśnie oświecony), JW, JWM (jaśnie wielmożny). Inne uzupełnienia ujęto w klamry.

${ }^{28}$ Przetlumaczenie listu znajdującego się $w$ drugim tomie ksiqżki francuskiej pod tytutem "Dyjaryjusz historyczny" przypisany Najjaśniejszemu Królewiczowi JMCi Polskiemu Klemensowi, elektorowi trewirskiemu, drukowanej we Frankfurcie nad Menem 1771, [b. m. dr.], 1771, 2 , s. [3] - egz. Biblioteki Narodowej w Warszawie sygn. XVIII.3.823; Centralny Katalog Starych Druków BN notuje m.in. blisko 20 egzemplarzy tego druku w ramach jednego klocka rękopiśmiennego (B Czart 796 IV, s. 179-322). W zbiorach BN znajduje się również egzemplarz innego wydania w formacie $4^{\circ}$, sygn. BN. XVIII.2.7. Odpisy: m.in. rps BJ 5501, k. 285-288 v.

${ }^{29}$ Omówienie Listu konfederata i tezy polemiki z nim zob. W. Konopczyński, Konfederacja barska, t. 2, Warszawa 1991, s. 881-890 (rozdz. XXIX: Publicystyka). Replika pt. Uwaga nad listem Antykonfederata $z$ dyjaryjuszu historycznego wyjetym..., zob. m.in. rps BJ 3049, s. 466-469; BN Akc. 1983, k. 141-142; BUW 274 t. IV, s. 1603-1606. 